\title{
Três elefantes: apropriações de Drummond pela poesia brasileira contemporânea
}

\author{
Fabio Weintraub ${ }^{1}$
}

\begin{abstract}
A princípio não quis aceitar o convite [para publicar na seção "Mês Modernista" do jornal A Noite], porque me pareceu que a gente d'A Noite ia apresentar-nos um pouco como o Sarrasani exibia no circo os seus elefantes ensinados. [...] Afinal concordei em colaborar, e a respeito dos elefantes Mário me escreveu: "Se você me dá os elefantes do Circo Sarrasani pra mim, faço uma das meias-colunas com isso. É um bom jeito de mostrar que a gente não cai na esparrela e em última análise nada mais somos que elefantes ensinados, nós artistas. Deixe de ser historiento que é isso mesmo!"
\end{abstract}

Manuel Bandeira, em Itinerário de Pasárgada

Se, como queria Eliot (1917/1989), a contemporaneidade de um escritor depende do modo pelo qual ele se situa em relação a seus pares de outrora, ao conjunto da tradição, verificar de que maneira ecoam na poesia presente as dicções prestigiosas do legado moderno (Bandeira, Drummond, Cabral, a vanguarda concreta etc.) pode constituir um valioso teste de sua contemporaneidade. Em que termos se formula, para a poesia atual, o vínculo com a tradição? Trata-se de herança (e a ressonância patrimonial é aí inevitável) ou de conquista? Do pacífico consumo do estoque de êxitos, do conjunto de formas e procedimentos acumulados ao longo do tempo, a despeito de qualquer nexo com a experiência presente, ou da verificação crítica do que ainda vale à luz das nossas circunstâncias?

No caso específico da recepção criativa de Drummond pelos poetas de agora, tal problema ganha novos matizes. Uma poesia bloqueada como é a dele, a qual responde formalmente a certos bloqueios históricos, não demandaria também dos poetas contemporâneos que o leem a experiência exasperada do bloqueio ao consumo indiscriminado

\footnotetext{
${ }^{1}$ Doutor em teoria literária e literatura comparada e professor colaborador da Universidade Federal de São Carlos (UFSCar), São Carlos, SP, Brasil. Eorcid.org/0000-0001-9226-641X. E-mail: fweintraub@usp.br
} 
de suas soluções expressivas? Desavisado ou consciente, o recalque desse bloqueio talvez se relacione, entre outras coisas, à monumentalização do legado drummondiano numa direção oposta à do ímpeto de quem encarecia o "canto rápido, ziguezaguante, rouco, / feito da impureza do minuto / e de vozes em febre" ("Mário de Andrade desce aos infernos").

A fim de averiguar de modo mais concreto o caráter museificante ou revitalizador da leitura do itabirano pelos poetas do século XXI, elegemos três poemas, de diferentes autores, os quais remetem ao poema "O elefante", de A rosa do povo (1945). São eles "Elefante", de Francisco Alvim, publicado no livro homônimo, de 2000; "Sentinela", de Chacal, publicado em Belvedere, de 2007; e "Atressi con l'orifanz", de Eduardo Sterzi, publicado em Aleijão, de 2009.

A escolha de "O elefante" como polo de diálogo para poetas contemporâneos de diferentes gerações não é casual: nele se repõe a figura da interrupção, marca registrada da poética do autor, presente em peças tão diversas como "No meio do caminho", "Áporo" e "A máquina do mundo", conforme esclarece o próprio Eduardo Sterzi (Sterzi, 2002, p. 86).

Iumna Simon destacará no poema a articulação entre o plano do conteúdo - a "metalinguagem do processo de construção da lírica social" (Simon, 1978, p. 75) - e o da expressão, em que se alternam trechos de grande abertura comunicativa, com estruturas hipotáticas, próximas da lógica linear-discursiva, e momentos de fechamento, marcados por cortes e estruturas paratáticas. Já Alcides Villaça se aterá especialmente à força dos símbolos nos quais se encarna a disposição participativa, examinando a articulação entre o impulso realista e o veio mitopoético. Para o crítico, o desmonte do mito ao final do poema e a disposição utópica para o recomeço representariam um passo além no tocante à repetição obsessiva, viciosa, interrompida apenas pela memória do cansaço, de "No meio do caminho" (Villaça, 2006, p. 75).

Não pretendemos, contudo, inventariar todas as leituras de "O elefante", bastando insistir no lugar de relevo que tal peça ocupa no conjunto da poesia drummondiana, dada sua complexidade construtiva. A atenção a esses aspectos nos permitirá aquilatar o potencial crítico da recepção do autor pelos poetas de hoje, à luz das exigências do presente. 
Desse modo, se em Alvim desaparecem as imagens de precariedade e de busca frustrada (bem como da disposição utópica para o recomeço), com prevalência do mito sobre o desmonte, sobressaem a feminização do animal e o contraste entre o que "rui por dentro" ("incêndio de pilastras", "céus atropelados") e o que vibra à volta dessa axis mundi, numa espécie de harmonia ideal, avessa à cognição ("A tua volta tudo canta. / Tudo desconhece). Já em "Sentinela", o périplo se interioriza ("um elefante passa em mim") sem prejuízo do sentimento de impasse, tão forte em Drummond ("teu ventre que abrange o mundo paralisado"), escamoteado pelo humor em face do berro lancinante do animal, feminizado como em Alvim.

Por fim, com Sterzi, a desmontagem do mito é antecipada pela destruição prévia dos elementos compositivos. A instabilidade aqui não advém do receio de uma desagregação futura, mas da percepção de uma fratura que já ocorreu, pois se trata de um bicho composto por meio da violência.

\section{Canta e desconhece}

Passemos então sem mais demora aos poemas, começando pelo de Francisco Alvim:

\section{Elefante}

$\mathrm{O}$ ar de tua carne, ar escuro anoitece pedra e vento.

Corre o enorme dentro de teu corpo

o ar externo

de céus atropelados. O firmamento, incêndio de pilastras, não está fora - rui por dentro.

Reverbera no escudo o brilho baço

do túrgido aríete

com que distância e tempo enfureces.

Teu pisar macio, dançarino, enobrece os ventres frios, femininos.

A tua volta tudo canta.

Tudo desconhece. 
Não seria o caso de coligir aqui as reiteradas menções à influência drummondiana em Alvim na fortuna crítica do autor. ${ }^{2}$ Sem embargo, se ao longo da obra do mineiro de Araxá é possível rastrear numerosos sinais desse convívio com o de Itabira e mesmo diálogos específicos como se vê em "Meio do caminho" e "Quatro contrafações", de O metro nenhum (2011), poemas que retomam explicitamente "No meio do caminho", de Alguma poesia (1930), e "Edifício São Borja", de A rosa do povo (1945) -, em "Elefante", composição que dá título ao livro de 2000, o confronto com o poema homônimo ${ }^{3}$ de $A$ rosa do povo mobilizará interpretações variadas da parte dos críticos. Flora Süssekind o caracterizará como poema-apóstrofe, em que

o animal passa de figura a interlocutor mudo, mas de uma descrição pautada e cindida, toda ela, por contradições como as que estruturam o poema de Drummond. E que incluem desde as imagens de um ar feito de carne, um firmamento que fica dentro, um brilho que reverbera, às tensões entre aberturas e fechamentos, claros e escuros vocálicos, entre o macio e o bélico, o prosaico da carne e do corpo e o escudo épico, a erotização (a intumescência, o ventre) e a abstratização (distância, tempo, ar) e entre atropelamentos e corrosões internas e um "a tua volta" no qual "tudo canta", "tudo desconhece" (Süssekind, 2000, p. 13).

Outros leitores, no entanto, reclamarão a influência de outros paquidermes. Em "Elefante à vista", texto anterior à publicação do poema de Alvim em livro, Sérgio Alcides relativizava o parentesco da fera com a congênere drummondiana, aproximando-a antes do "Elefante de Celebes", de Max Ernst:

Enigmático, o poema-título deixa a impressão de que o poeta cedeu à tentação da metáfora, de que vinha se afastando desde Passatempo (1974). Mais do que metáfora, vemos aqui uma

\footnotetext{
${ }^{2}$ Roberto Schwarz, por exemplo, em um dos mais importantes ensaios sobre Elefante, vai destacar de que maneira, na obra de Alvim, o minimalismo e o pitoresco oswaldianos são corrigidos pelo pessimismo drummondiano (Schwarz, 2012, p. 142).

${ }^{3} \mathrm{Na}$ verdade, quase homônimo, pois a supressão do artigo no poema de Alvim dá o que pensar. Villaça, falando do elefante drummondiano, começa sua interpretação dizendo que a mudança do artigo definido do título para o indefinido do primeiro verso ("Fabrico um elefante") constitui uma primeira modulação expressiva, a passagem do referente empírico, genérico, "natural" para o de artifício, singular (Villaça, 2006, p. 64). No poema de Alvim, a supressão do artigo indica talvez o caminho inverso, de passagem do empírico ao mítico, numinoso.
} 
sucessão de metáforas - "ventres frios", "céus atropelados", "incêndio de pilastras" - imagens em debandada. Como na tela de Ernst, o resultado é mais alegórico que metafórico; trata-se, porém, de uma alegorização que não se restringe a um tema [...] já que também envolve o procedimento adotado (colagem, montagem, assemblage) e ainda um certo "modo" (a ironia, o distanciamento, a corrosão). A esquivança desse "Elefante", afinal, imita a do próprio bem que ele alegoriza e que a "voz" do poema almeja ("A tua volta tudo canta / Tudo desconhece") (Alcides, 1999, p. 17-18).

Em entrevista a Alcides, o poeta endossa tal relativização:

[...] vou um pouco num sentido contrário à questão do gauche, talvez porque eu tenha visto o elefante. A ideia do elefante e sua beleza foram para mim uma coisa muito real. Eu estava no Quênia e vi um grupo de elefantes se acercando do lugar em que estávamos almoçando. Isso provocou uma reação imediata, porque era uma coisa tão encantadora. Deviam ser umas elefoas com uns dois ou três elefantinhos era um bando de elefantes. Todos saíram correndo, e aí os garçons da reserva vieram alucinados, dizendo: "São feras! São feras!". Porque o impulso era de beleza, de vontade de se acercar, de tranquilidade, de harmonia. E aí nós ficamos olhando. Era muito diferente de vê-los num circo ou num zoo. Pela primeira vez eu vi aquela maravilha que era um elefante. Era um ser cheio de vento, como está no poematítulo do livro. Era uma coisa de canto, de música, que envolvia, e ao mesmo tempo de escuridão, aquela massa tremenda. Então, o elefante para mim tem um sentido que a minha poesia não tem, pelo menos não na sua grande vertente, que é um sentimento de harmonia, "A tua volta tudo canta. / Tudo desconhece", quer dizer: o que produz o enguiço, a problematização, a infelicidade, é exatamente a ausência de canto e a presença do conhecimento, coisas que a minha poesia tem frequentemente. Acho que aquele elefante, ao contrário, nasceu a favor da corrente, e não contra: ele não vai a contrapelo (Alvim, 2002, p. 199). 
As referências se multiplicam: além do quadro de Marx Ernst, os elefantes de Dalton Trevisan, "com quem o poeta confessou ter aperfeiçoado o corte justo e a perfeição da elipse", conforme explica Vilma Arêas na orelha do livro (Arêas, 2000), ou a dança dramática do "Maracatu-nação do Elefante", segundo Maria Augusta Fonseca (Fonseca, 2001, p. 89). Como conciliar referências tão díspares? E qual seu peso, comparado ao do vínculo com o elefante drummondiano?

Em favor da afirmação daquele vínculo, vale lembrar que, no livro de Alvim, a composição é sucedida por outra, intitulada "Poema", dedicada a Drummond. Entre ambas, nota-se a recorrência de elementos da natureza, como sombras, vento, lagos e astros, e grande convergência nos desfechos, relacionados com a ideia de um eixo ao redor do qual as sombras giram ("Poema") e "tudo canta. / Tudo desconhece" ("Elefante").

Mas talvez apenas a dedicatória pareça insuficiente para assegurar a remissão do poema ao antecedente drummondiano. De fato, as diferenças entre os elefantes chamam mais a atenção que as semelhanças. Conquanto a metalinguagem constitua um fundo comum a ambos, em Alvim ela não se refere aos impasses no processo de construção de uma lírica social. O poema parece transcorrer em um tempo mítico, a-histórico, em que as ações carecem de qualquer menção aos homens e à vida em sociedade.

A linguagem também é muito diversa, tendendo a um registro mais alto e formal em função do uso da segunda pessoa, de certas inversões ("com que distância e tempo enfureces"), e da escolha lexical, que inclui termos como "firmamento", "baço", "túrgido", "aríete" etc.

No plano imagético, chamam a atenção as figuras de destruição (incêndio, céus atropelados, ruína, aríete), ao mesmo tempo interiores e exteriores, numa reversibilidade característica da poética do autor. Assim é que o ar da carne anoitece o que está fora, pedra e vento, e o céu, em chamas e atropelo, corre dentro do corpo.

Cumpre atentar para o nexo estrito entre os dois primeiros versos, dado pela permutação entre elementos equivalentes: “o ar da carne", desdobra-se em vento (ar) e pedra (massa sólida e inerte, carne sem sopro), cujo anoitecer deriva igualmente de sua escuridão constitutiva, fonicamente reforçada nos versos seguintes pela variação no timbre vocálico dos fonemas terminados em " $r$ ": cARne/AR > enORme/cORpo. Tal ar, desentranhado do vocábulo 
carne, vai aparecer três vezes (ar carnal, ar escuro, ar externo), exteriorizando-se em "expirações" correspondentes à internalização do céu. Do ponto de vista construtivo, o jogo entre o que sai e o que entra é também reforçado pelo isolamento progressivo dos apostos e pelo recurso ao enjambement: o primeiro aposto do poema vem colado ao sujeito do primeiro período em um verso único, os seguintes (o ar externo de céus atropelados, incêndio de pilastras) se separam e fracionam, mimetizando o conteúdo acidentário (atropelo, incêndio, ruína) dos versos.

No plano simbólico, há no poema algo do elefante cosmóforo, que, na mitologia da Índia e do Tibete, desempenha a função de cariátide, suporte do mundo, "por causa da semelhança de sua estrutura com a do cosmos: quatro pilares que sustentam uma esfera" (Chevalier e Gheerbrant, 2009, p. 360).

As pilastras em chamas, por seu turno, lembram as de um poema mais antigo do autor, "Píer", de Lago, montanha (1981), no qual um "incêndio de cobre nas pilastras" vara de luz os corpos na praia.

As imagens dos três últimos versos da primeira estrofe aludem a um contexto épico, bélico (escudo, aríete) em que a harmonia concertante do final é precedida pela violência de transformações cósmicas. Um eixo vertical (pilastra), que une a carne ao céu, junta-se à horizontalidade do aríete, num contexto de múltiplas polaridades (escuridão $\times$ brilho; turgor $\times$ maciez; choque $\times$ dança), condensadas às vezes numa expressão como "brilho baço" e delicadamente abarcadas numa rede irregular de discretas rimas: vento/firmamento/dentro, dançarino/femininos, enfureces/desconhece.

A passagem da primeira para a segunda estrofe, do bélico ao erótico, é antecipada pelo adjetivo que qualifica o aríete, "túrgido", o qual evoca a rigidez do que é vivo, do que se excita, se enche de sangue. Trata-se de um símbolo fálico, viril, ligado ao background simbólico do animal, que em diversas culturas representa tanto a energia sexual, fecundante, quanto a potência destrutiva?4 Ao que tudo indica, não, pois a segunda estrofe, em seu último verso, nos surpreende com a informação de que o paquiderme em questão é uma fêmea, uma elefanta, conforme já

\footnotetext{
${ }^{4}$ Por exemplo, na cultura hindu, em que Ganesha, a divindade com cabeça de elefante, é ao mesmo tempo o deus dos exércitos e também aquele que insemina Maya e gera Buda, conforme explica Denise Ramos (Ramos, 2005, p. 134).
} 
sugerira o próprio autor ao mencionar o episódio no Quênia com as "elefoas", anteriormente citado. "Teu pisar macio, dançarino, / enobrece os ventres frios, femininos". Passa-se do firmamento ao chão, o "passo desastrado / mas faminto e tocante" do disfarce drummondiano vira aqui dança feminina, contemplada à distância pelo eu lírico, ciente de sua alteridade.

A mudança de gênero de alguma forma ajuda a entender melhor a indiferenciação entre exterior e interior presente na primeira estrofe, como se tal abolição de limites estivesse relacionada com o feminino como princípio fusional - o receptivoescuro, associado à terra, por oposição ao criativo-luminoso, associado ao céu, para lembrar dos hexagramas iniciais do Livro das mutações ${ }^{5}$-, com predomínio das sensações sobre os conceitos, do canto sobre o discurso, conforme se vê no dístico derradeiro, de totalização musical, que suprime de vez as distâncias e oblitera as brechas necessárias ao conhecimento.

No plano formal, a revelação do princípio feminino, que corresponde à superação da turbulência furiosa da primeira estrofe, repleta de imagens de desastre e colisão, é marcada pela diminuição progressiva no tamanho dos versos, com 9, 7 e 3 sílabas poéticas, respectivamente, e pela concentração em uma rima única (macIO, dançarINO, frIOs, femININOs), em contraste com a variação das vogais tônicas na estância antecedente. Temos então uma espécie de remanso, de calmaria, patente também nos atributos do bicho; de um lado, a graça e a suavidade, de outro, a altivez e a indiferença (a nobreza dos ventres frios). Paradoxalmente, esse remanso não serviria também para revelar algo do interlocutor que se dirige à fera? Se na primeira estrofe o que transparece é sobretudo o assombro diante do incomensurável ("Corre o enorme") e da troca

\footnotetext{
${ }^{5} \mathrm{O}$ segundo hexagrama, "K’um / O receptivo" representa "a natureza em contraste com o espírito, a terra em contraste com o céu, o espaço em contraste com o tempo e o feminino-maternal em contraste com a masculino-paternal" (Wilhelm, 1999, p. 33). Ainda com relação ao feminino como princípio fusional, vemos em Freud certo "horror ao materno", entendido como lugar de fusão e retorno ao indiferenciado. Em Moisés e o monoteísmo (1939), ele chega a comentar a passagem da ordem matriarcal para a patriarcal como triunfo do pensamento sobre a sensualidade: "esse afastamento da mãe para o pai aponta, além disso, para uma vitória da intelectualidade sobre a sensualidade - isto é, para um avanço em civilização, já que a maternidade é provada pela evidência dos sentidos, ao passo que a paternidade é uma hipótese, baseada numa inferência e numa premissa. Tomar partido, dessa maneira, por um processo de pensamento, de preferência a uma percepção sensória, provou ser um passo momentoso" (Freud, 1975, p. 136).
} 
entre exterior e interior, a redução de escala (o olhar sobre o ventre cadenciado pelo andar) e a nobre indiferença parecem seduzir o eu lírico, como se a frieza lhe acendesse o desejo.

Tudo isso prepara o momento de harmonia do desfecho, que dialoga com o final da peça seguinte, "Poema", em que, novamente, o "ar escuro" de que são feitas as sombras gira em torno de uma coluna sonora, o poema, em que a luz de dentro se exterioriza. Elefanta e poema se equivalem, funcionando como axis mundi, eixo produtor de uma harmonia inconsciente ("Tudo desconhece").

No poema drummondiano, algo próximo desse ideal de harmonia aparece na penúltima estrofe, em que se acumulam imagens naturais marcadas pela ideia de interioridade, como explica Alcides Villaça, "situações patéticas" prenhes de uma verdade essencial a que se quer chegar, paradoxalmente, por meio de um artifício, o que põe a nu "o descompasso entre necessidade natural e o engenhado produto que pretende encarná-la" (Villaça, 2006, p. 69-70). No livro de Alvim, porém, tal descompasso não comparece no espaço mítico do poematítulo, mas, sim, no atrito entre as peças líricas e as de "escuta do mundo", entre os ruídos da existência comezinha e "o sofrimento pela perda imaginária de uma totalidade anterior à vida", conforme observou o crítico Sérgio Alcides (2016, p. 32). ${ }^{6}$

Essa dissociação entre a música total e os ruídos do mundo devese também em parte à mudança na posição do eu lírico, o qual deixa de ter papel ativo (que vai do "fabrico um elefante" até o "amanhã recomeço") para se tornar apenas espectador, intensamente afetado pela potência de seu interlocutor, a quem se dirige em segunda pessoa. Conforme Fabiane Borsato, tal paralisia, igualmente presente em "Sentinela", de Chacal, corresponderia a um tipo de estupefação intertextual em que a ação passa a se reduzir à competência discursiva e ao desejo de mundo "à busca de conjunção com a poesia-elefante" (Borsato, 2011, p. 3),

\footnotetext{
${ }^{6}$ Opinião diversa é sustentada por Carolina Serra Azul, para quem, mesmo nas peças mais líricas, a mitologia do eu é contida pela "constante invasão de elementos objetivos". Afirma a autora: "As muitas sombras do mundo exterior - a segunda natureza - fazem frente à primeira, degradando os momentos de epifania latente que irrompem destes breves instantes líricos" (Azul, 2013, p. 89). Em sua dissertação de mestrado, Heitor Ferraz Mello dirá, a propósito de "Elefante", que tal poema constituiria uma espécie de avesso da poética do autor (onde o desejo de cognição impede o canto), funcionando como uma "epifania desencantada" (Mello, 2001, p. 217).
} 
De qualquer maneira, se nesse poema isolado a música total e inconsciente põe em surdina os ruídos do mundo, eles seguem soando em outros poemas do livro, de viés mais crítico, realista, problematizando de outra maneira a saída mítica como resposta à reificação geral.

\section{O cio e o hidrante}

Vejamos a seguir o segundo poema, publicado por Chacal sete anos mais tarde:

\section{Sentinela}

teu jeito de elefanta contraído me angustia.

quem sou eu, quem és tu nessa manhã que se anuncia?

sentinela, minha nega, estou tomado pelo teu sentimento.

posso dizer que um elefante passa em mim.

com seu passo lerdo, um tanto tardo de ser.

quando tu assoas tua tromba, sentinela, me assombra.

quem não ficaria sem ar com o teu passar resfriado

com teu ventre que abrange o mundo paralisado?

sentinela sentinela quem te deu esse nome bacana?

por que sais de manhã toda trêfega e só voltas sei lá quando?

sentinela, esse jeito avoado de quadrúpede no cio me assanha.

alguns te chamam elefanta, outros aliá e todos têm razão

menos eu sentinela, menos eu que sou assolado pelo teu

sentimento.

por que não vieste a esse mundo, um walkie talkie, um

discman?

assim poderia operá-la ou escutar hendrix quando quisesse. mas não. vieste elefante e para escutar teu berro lancinante teu ronco visceral, fico impassível como um hidrante.

vai, sentinela, vai!

cambaleante pelas ruas do rio. boa sorte. seja feliz. até logo.

No I Encontro Mundial de Invenção Literária, ocorrido em São Paulo, em novembro de 2015 (Rodrigues, 2015), Chacal realizou leitura pública de poemas na Livraria da Vila. Indagado sobre a gênese de "Sentinela", especificamente sobre a importância do poema de Drummond como eventual deflagrador, Chacal preteriu as supostas fontes literárias, afirmando que o poema havia nascido 
de uma experiência de decepção amorosa: uma menina com quem ele namorava havia acordado gripada e com um tremendo mau humor. Foi quanto bastou para que a sensibilidade do poeta a convertesse na paquiderme descrita pelo poema.

Sem menosprezar eventuais componentes biográficos como gatilhos da imaginação, mas também sem superestimar as declarações do poeta como interpretação autorizada, o poema guarda sinais inequívocos de débito em relação ao elefante do itabirano.

O périplo aqui é interior ("um elefante passa em mim") e exterior ("cambaleante pelas ruas do rio"), como de certa forma em Drummond, onde o elefante é anseio e meio de transporte. A relação empática com a fera ("estou tomado pelo teu sentimento") é também, para lembrar outra expressão drummondiana, "sentimento do mundo" ("teu ventre abrange o mundo paralisado"), configurando um impasse que excede a intimidade do casal.

Claro que todos esses elementos vêm filtrados pela informalidade e pela ironia características do autor, que mistura registros de linguagem, alternando fórmulas sentenciosas e altissonantes ("quem sou eu, quem és tu?) com expressões informais e gírias ("nome bacana", "toda trêfega", "quadrúpede no cio"). O uso da segunda pessoa é propositadamente canhestro, como se vê no sexto verso ("quando tu assoas tua tromba, sentinela, me assombra" em vez de "me assombras"), e os desvios em face da correção formal bem como a digressão sobre as possibilidades de nomeação da fera ("alguns te chamam elefanta, outros aliá") acabam servindo para figurar o sentimento de inadequação do sujeito lírico ("todos têm razão / menos eu").

Ainda no campo dos nomes, chama a atenção o vocativo "sentinela", com que o sujeito lírico se dirige à interlocutora. Tal termo designa o indivíduo isolado em um posto de observação (relacionando-se assim com a ideia de belvedere, título do livro onde o poema se encontra) mas também, jocosamente, à semelhança do nome de outros personagens de Chacal, como Orlando Tacapau, Genival Bundamental etc., à combinação entre o verbo "sentir", conjugado na primeira pessoa do pretérito perfeito do indicativo, e o pronome "nela", associando, portanto, distância e empatia.

Se em Alvim a fragilidade do animal drummondiano cede lugar à fúria em chave bélica e erótica, em Chacal o erotismo também dá as caras, mas em chave rebaixada: o ronco visceral, o berro lancinante é 
condição transitória de fêmea no cio, que mobiliza em suas vítimas seja o desejo de reificação ("por que não vieste a esse mundo um walkie talkie, um discman?"), seja o de autorreificação ("fico impassível como um hidrante") - desejos criticamente representados como sombras da utopia amorosa, rebaixada à esfera do consumo e da segurança.

As transformações não são arbitrárias: walkie talkie e discman, aparelhos sonoros cuja "fala" pode ser interrompida ou controlada (talvez à diferença do autofalante de queixumes da companheira emburrada), e "hidrante", em função da rima não apenas sonora mas também imagética com o elefante, cuja tromba espirra água, assemelhando-se à mangueira do equipamento contra incêndios.

No entanto, em face da ameaça de cio e incêndio, conforme sugere a figura do hidrante, o sujeito lírico renuncia ao esforço de controle e defesa, fica impassível, mas relaxa a seguir em uma despedida na qual também a promessa de um recomeço se aligeira em fórmulas protocolares ("boa sorte. seja feliz. até logo"), mobilizadas com uma sinceridade brincalhona que lembra o "muito prazer" do livro de estreia do autor.

Numa interpretação discordante da minha, Fabiane Borsato lê o final do poema como coroamento de um processo "de reificação paulatina até a total passividade e automatismo" (Borsato, 2011, p. 7). Eu, ao contrário, vejo nesse despacho um discreto gesto de libertação, marcado inclusive formalmente pela passagem da fieira de interrogações à exclamação final, que abre alas para a fera. Como a doçura do bicho drummondiano aqui desandou em azedume, o poema do carioca termina onde o do mineiro começava: na rua povoada.

Configura-se assim, julgo eu, uma retomada de certas imagens e questões do poema drummondiano que se afasta da alusão gratuita, do mero decalque ou da reciclagem de estilemas alheios, respondendo antes a inquietações singulares que acompanham Chacal há bastante tempo.

\section{Fratura prévia}

Para concluir, vejamos o último elefante da nossa coleção, o poema "Atressi con l'orifanz", de Eduardo Sterzi, dos três, aquele que guarda um diálogo mais cerrado com o antecedente drummondiano. 


\section{Atressi con l'orifanz}

Ânimo de argamassa

mal-sovada, andaime

de ossos rotos

mal e

mal

sustendo

o bruto corpo

inflável, in-

flamável.

E,

quando,

depois do fogo,

depois do

dilúvio,

a pele

escorchada

entupir

bocas-

de-lobo:

aperte o passo,

evite a polícia,

esqueça

isso

que eu era. 
Conforme revela o próprio autor, ${ }^{7}$ o título do poema, em provençal, vem de Rigaut de Berbezihl (1140-1163), em francês, Rigaud de Barbezieux - trovador provençal, citado no Roman de la rose. Esse trovador, falecido muito jovem, deixou diminuta obra, apenas quinze poemas, exercendo todavia grande influência sobre a tradição lírica e os bestiários medievais (dois dos poemas são cantigas sobre bichos). "Atressi con l'orifanz" vem dos versos iniciais de seu poema mais conhecido: "Assim como o elefante / que quando cai não consegue se erguer".

Tal acesso ao elefante drummondiano por um desvio medieval sugere de imediato um desfecho menos promissor para o paquiderme-poema, cuja queda parece incontornável ("quando cai não consegue se erguer").

À parte esse afastamento do poema-modelo, vemos que também aqui a construção do animal simbólico com que o poeta se disfarça utiliza materiais precários: ossos rotos, argamassa mal sovada, alicerces frágeis, incapazes de suster "o bruto corpo". Reconhece-se, ademais, a natureza heteróclita dos elementos da composição, feita de argamassa e ânimo, ossos, pele e combustível.

No entanto, se no elefante de 1945 o desmonte do mito ao final era antecipado pela falta de recursos, pelo improviso e pela união insegura entre as partes desajustadas, unidas por cola e costura, em "Atressi con l'orifanz" a ameaça de desconchavo deriva da destruição prévia dos elementos compositivos. Não se trata de um agrupamento instável, sujeito à desagregação futura, mas da consciência de uma fratura que já ocorreu: os ossos estão rotos e, no lugar da cola e da costura, o princípio aglutinador é a sova, a violência.

À violência no plano do conteúdo corresponde, no plano da expressão, uma sequência de quebras sintáticas e espaciais. Os nove

\footnotetext{
7 "Tomei a expressão de empréstimo do incipit de um poema de Rigaut de Berbezilh, que li quando estava pesquisando o trovadorismo occitânico para a realização da minha tese de doutorado sobre Dante. Fiquei muito impressionado com o início deste poema, com a força da analogia ali traçada por Rigaut: 'Assim como o elefante, / que quando cai não consegue se levantar'. Lembrei-me de imediato de dois textos fundamentais da poesia brasileira moderna e contemporânea: 'O elefante', de Drummond, que citei há pouco, e o 'Elefante', de Francisco Alvim. A imagem da queda e da dificuldade de se reerguer no poema de Rigaut ficou me martelando, misturando-se com as imagens dos poemas de Drummond e Alvim e, em dado momento, o poema veio quase de um jato, estranhamente solicitando uma forma muito entrecortada, cheia de saliências, pontas" (Lima, Mello e Sterzi, 2011, p. 207).
} 
versos iniciais compõem período único, sem verbos, com grande variação na extensão métrica (entre uma e seis sílabas), isolamento e repetição de palavras-chave, como o advérbio "mal" (inicialmente anexado ao adjetivo "sovada" e depois livre e duplicado, na segunda estrofe) e o prefixo "in" (despregado de seu complemento na quarta estrofe, com uma linha em branco antes do nono verso). Aliás, após essa quebra do prefixo "in", é como se o terceiro dístico de uma sequência de três (versos 4 a 9) tivesse se desconjuntado, depois de inflar e arder, o que torna a ocorrer nos cinco versos finais, em que a exigência de fuga força um maior distanciamento entre os versos.

Aceso o corpo "flamável", o desastre se alastra em imagens de fogo e dilúvio, que, em função da falta de alvos específicos, trazem algo de indeterminado e mítico, por causa da ressonância bíblica do termo "dilúvio" e da alternância abrupta entre forças destrutivas complementares, fogo e água. A indeterminação, no entanto, desaparece na oitava estrofe (versos 15 a 19), quando, por meio da "pele escorchada", que se conecta aos "ossos rotos" do início, reaparece a referência a um corpo e a um cenário específico, urbano, indicado pela menção às "bocas-de-lobo", expressão novamente quebrada, como antes ocorrera com o adjetivo "inflamável". Vale observar que a sequência de quebras é de certa forma compensada no plano fônico pela amarração entre palavras dissílabas, paroxítonas, com "o" fechado (rotos/corpo/fogo/lobo).

Novamente os versos 10 a 19 compõem uma oração subordinada adverbial temporal, cujo complemento, formado por uma sequência de três imperativos ("aperte", "evite", "esqueça") só aparece nos cinco versos finais, que promovem uma reviravolta.

Até aqui, conforme buscamos evidenciar, indicamos como as imagens de violência tinham algo de indeterminado, seja na composição (ou recomposição) de um "bruto corpo", não referido a nenhum sujeito específico (tirando o elefante do título, em momento algum se nomeia o dono do corpo), seja nas imagens seguintes de incêndio, dilúvio e esfolamento, que só com a menção às bocas-delobo passam a se referir a um cenário e a um tempo definidos. Das bocas-de-lobo passamos então à repressão policial, quando o poema parece dar uma guinada. Graças a ela, o imaginário apocalíptico mobilizado pelo poema escapa de um destino meramente retórico e se encaminha para um desenlace tenso e muito vivo. Tal guinada é 
acompanhada do aparecimento inesperado de uma segunda pessoa, um interlocutor a quem se dirige o eu lírico e com quem o leitor pode se identificar. A esse interlocutor são dirigidas as frases imperativas criando uma espécie de cumplicidade no perigo. Cumplicidade que dialoga de modo complexo com a frustração do elefante drummondiano, o qual, invisível em meio à rua povoada e indiferente, retorna insaciado em suas fomes e despeja seu vasto engenho sob o tapete. Aqui, ao contrário, vemos um esboço de encontro e solidariedade a poucos centímetros do cassetete e da bomba. Mas se trata de uma solidariedade que dissolve o vínculo entre o eu lírico e seu interlocutor, no poema ou fora dele, pois a oportunidade de salvar-se está condicionada ao esquecimento, à perda de identidade ("esqueça isso que eu era"). Engenhosamente, o momento de maior espessamento da tessitura fônica, dado pelo excesso de sibilantes em posição próxima ("passo/polícia/isso/esqueça"), é acompanhado do esgarçamento dos laços intersubjetivos no instante de perigo, numa espécie de cicio terrível em que o "salve-se quem puder" autoriza não olhar para trás.

Numa primeira leitura, pode parecer que a falta de um equivalente do "amanhã recomeço" revela uma relação enfraquecida com o poema-fonte, dado o desaparecimento de um de seus componentes essenciais. No entanto, a habilidosa representação de uma situação extrema em que a sobrevivência passa a definir o limite da solidariedade não elide o traço utópico que religa este "orifanz" ao elefante que o precede: a generosidade de se deixar esquecer para que o outro se salve.

\section{A potência dos recomeços}

Para retornar ao início: se a contemporaneidade da poesia atual depende de seu esforço de arrancar a tradição ao conformismo, descartando o que se tornou obsoleto, verificamos nesses três diálogos com "O elefante" uma apropriação inventiva, que desloca as leituras sedimentadas em torno da obra de Drummond à luz das inquietações do presente.

Em Alvim, os impasses da lírica participante ativos no poema-fonte são aparentemente afastados pelo encaminhamento da metalinguagem para uma esfera mítica, precognitiva (em 
tensão, porém, com poemas de viés mais realista, nos quais os ruídos mundanos seguem soando em contracanto à sereia de tromba). Tal dissociação entre mítico e político, aspectos inextricáveis no paquiderme drummondiano, talvez revele algo das mutações do "mundo enfastiado", quando a falta de horizontes e a baixíssima coesão social sequer configuram a carência de amigos, outrora frustrada.

Em Chacal, prossegue a feminização/erotização do animal protagonista, cujo transtorno comportamental provocado pelo cio conduz a desejos de reificação e autorreificação, reduzindo os agentes amorosos a bens de consumo e equipamentos de segurança.

Por fim, em Sterzi - entre os três poetas aqui examinados aquele que se mantém mais próximo da dimensão política do poema drummondiano -, vemos ressurgir o problema da segurança (tratado por Chacal de modo leve e jocoso) em chave dramática, possível testemunho de uma circunstância histórica em que a repressão policial e a militarização da política voltam à tona, reforçando a percepção de continuidade com práticas ditatoriais em tempos formalmente democráticos.

Assim, seja pela nostalgia de uma música total, perdida em meio ao alarido dos homens, seja pelo anseio de uma experiência amorosa sem trombas e sombras, seja por meio dessa solidariedade esquisita, feita de fuga e esquecimento, ressoa a potência dos recomeços.

\section{Referências}

ALCIDES, Sérgio (1999). Elefante à vista. In: AZEVEDO, Carlito; GUIMARÃES, Júlio Castañon (Dir.). Inimigo Rumor. Rio de Janeiro: 7Letras. n. 6 .

ALCIDES, Sérgio (2016). A dança do Elefante entre as palavras. In: ALCIDES, Sérgio. Armadilha para Ana Cristina. Rio de Janeiro: Verso Brasil.

ALVIM, Francisco (2000). Elefante. São Paulo: Companhia das Letras.

ALVIM, Francisco (2002). Ela finge, ela se disfarça, ela é muito sonsa. Entrevista a Sérgio Alcides. In: Rodapé: crítica de literatura brasileira contemporânea. São Paulo: Nankin. n. 2.

ALVIM, Francisco (2004). Poemas (1968-2000). São Paulo: Cosac Naify. 
ALVIM, Francisco (2011). O metro nenhum. São Paulo: Companhia das Letras. AREAAS, Vilma (2000). Orelha para Elefante. In: ALVIM, Francisco. Elefante. São Paulo: Companhia das Letras.

AZUL, Carolina Serra (2013). O eu impossível de Francisco Alvim. In: DAMAZIO, Reynaldo; MELO, Tarso de (Org.). Literatura e cidadania: dilemas entre estética e política no Brasil contemporâneo. São Paulo: Dobra.

BANDEIRA, Manuel (1984). Itinerário de Pasárgada. 3. ed. Rio de Janeiro: Nova Fronteira; Brasília: Instituto Nacional do Livro.

BORSATO, Fabiane Renata (2011). Sentinelas poéticos: os elefantes de Drummond, Alvim e Chacal. Cadernos de Semiótica Aplicada, Araraquara, v. 9 , n. 2 .

CHACAL (2007). Belvedere. São Paulo: Cosac Naify.

CHACAL (2016). Tudo (e mais um pouco). Poesia reunida (1971-2016). São Paulo: 34.

CHEVALIER, Jean; GHEERBRANT, Alain (2009). Dicionário de símbolos. 24. ed. Rio de Janeiro: José Olympio.

ELIOT, Thomas Stearns (1917/1989). Tradição e talento individual. In: ELIOT, Thomas Stearns. Ensaios. Tradução, introdução e notas de Ivan Junqueira. São Paulo: Art. p. 37-48.

FONSECA, Maria Augusta (2002). Inconfidências poéticas de Elefante. Literatura e Sociedade, São Paulo, v. 7, n. 6, p. 84-104.

FREUD, Sigmund (1939/1975). Moisés e o monoteísmo. In: FREUD, Sigmund. Edição standard brasileira das obras psicológicas completas de Sigmund Freud. Moisés e o Monoteísmo, Esboço de Psicanálise e outros trabalhos. Rio de Janeiro: Imago, 1975. v. 23.

LIMA, Manoel Ricardo de; MELLO, Heitor Ferraz; STERZI, Eduardo (2011). A conversa com o dedo apontado para um cadinho menos literário do poema. Entrevista concedida a Leonardo Gandolfi. In: BASTOS, Dau et al. (Org.). Fórum de Literatura Brasileira Contemporânea 3. Rio de Janeiro: Torre. p. 201-2015. Disponível em: <https:/ / bit.ly/2Lte8O3>. Acesso em: 25 set. 2017.

MELLO, Heitor Ferraz (2001). O rito das calçadas: aspectos da poesia de Francisco Alvim. Dissertação (Mestrado em Letras) - Universidade de São Paulo, São Paulo.

RAMOS, Denise Gimenez et al. (2005). Os animais e a psique. São Paulo: Summus. v. 1. 
RODRIGUES, Maria Fernanda (2015). Três festivais literários movimentam São Paulo. O Estado de S. Paulo, São Paulo, 6 nov. Disponível em: <https://bit.ly/2MSZZhO>. Acesso em: 25 set. 2017.

SCHWARZ, Roberto (2012). Um minimalismo enorme. In: SCHWARZ, Roberto. Martinha versus Lucrécia. São Paulo: Companhia das Letras.

SIMON, Iumna (1978). Drummond: uma poética do risco. São Paulo: Ática.

STERZI, Eduardo (2002). Drummond e a poética da interrupção. In: DAMAZIO, Reynaldo. Drummond revisitado. São Paulo: Unimarco.

STERZI, Eduardo (2009). Aleijão. Rio de Janeiro: 7Letras.

SÜSSEKIND, Flora (2000). O real da poesia. Folha de S. Paulo, São Paulo, Caderno Mais!, 19 nov. Disponível em: <https://bit.ly/2wlznvu>. Acesso em: 25 set. 2017.

VILLAÇA, Alcides (2006). Um elefante de mentira e de verdade. In: VILLAÇA, Alcides. Passos de Drummond. São Paulo: Cosac Naify.

WILHELM, Richard (1999). I Ching. O livro das mutações. São Paulo: Pensamento.

Recebido em 26 de setembro de 2017.

Aprovado em 30 de janeiro de 2018.

\section{resumo/abstract/resumen}

\section{Três elefantes: apropriações de Drummond pela poesia brasileira contemporânea}

Fabio Weintraub

Tendo em vista a recepção criativa da obra de Carlos Drummond pela poesia brasileira contemporânea, este artigo examina os poemas "Elefante", de Francisco Alvim, "Sentinela", de Chacal, e "Atressi con l'orifanz", de Eduardo Sterzi, à luz do diálogo que tais composições estabelecem com "O elefante" de A rosa do povo (1945). Entre outros deslizamentos em relação à fonte drummondiana, destacam-se a feminização do animal como meio de acesso à esfera mítica, em Alvim; a interiorização do périplo paquidérmico, em Chacal, e a violência como modo compositivo, em Sterzi.

Palavras-chave: poesia brasileira contemporânea, Carlos Drummond de Andrade, Francisco Alvim, Chacal, Eduardo Sterzi. 
Three elephants: appropriations of Drummond by contemporary Brazilian poetry

Fabio Weintraub

In view of the creative reception of Carlos Drummond de Andrade's work by contemporary Brazilian poetry, this article analyzes the poems "Elefante", by Francisco Alvim, "Sentinela", by Chacal, and "Atressi con l'orifanz", by Eduardo Sterzi, in light of the dialogue that such compositions maintain with "The Elephant" published in Rose of the People (1945). The article highlights, among other slippages in relation to Drummond de Andrade's poem, the feminization of the animal as a means of accessing a mythical sphere, in Alvim; the internalization of the pachyderm's trajectory in Chacal, and violence as a compositional mode in Sterzi.

Keywords: contemporary Brazilian poetry, Carlos Drummond de Andrade, Francisco Alvim, Chacal, Eduardo Sterzi.

\section{Tres elefantes: apropiaciones de Drummond por la poesía brasileña contemporánea}

Fabio Weintraub

Considerando la recepción creativa de la obra de Carlos Drummond de Andrade por la poesía brasileña contemporánea, el presente artículo examina los poemas "Elefante", de Francisco Alvim, "Centinela", de Chacal, y "Atressi con l'orifanz", de Eduardo Sterzi, a la luz del diálogo que dichas composiciones establecen con "El elefante" de La rosa del pueblo (1945). Entre otros deslizamientos en relación a la fuente drummondiana, se destacan la feminización del animal como medio de acceso a la esfera mítica, en Alvim; la interiorización del periplo paquidérmico, en Chacal, y la violencia como modo compositivo, en Sterzi.

Palabras clave: poesía brasileña contemporânea, Carlos Drummond de Andrade, Francisco Alvim, Chacal, Eduardo Sterzi. 